\title{
Responses of Upland Rice cv Inpago LIPI Go4 to Microbial Inoculant and Nitrogen Fertilization Dosage Treatments
}

\author{
Reni Lestari ${ }^{1}$, Kartika Ning Tyas ${ }^{1}$, Arief Noor Rachmadiyanto ${ }^{1}$, Didi Usmadi ${ }^{1}$, Mahatma Gandhi ${ }^{1}$, \\ Hendra Helmanto ${ }^{1}$, Frisca Damayanti ${ }^{1}$, Rizmoon Nurul Zulkarnaen ${ }^{1}$, I. Made Sudiana ${ }^{2}$ \\ $\&$ Enung Sri Mulyaningsih ${ }^{3}$ \\ ${ }^{1}$ Research Center for Plant Conservation and Botanic Gardens, Indonesian Institute of Sciences, Indonesia \\ ${ }^{2}$ Research Center for Biology, Indonesian Institute of Sciences, Indonesia \\ ${ }^{3}$ Research Center for Biotechnology, Indonesian Institute of Sciences, Indonesia \\ Correspondence: Reni Lestari, Research Center for Plant Conservation and Botanic Gardens, Indonesian Institute \\ of Sciences, Jl. Ir. H. Juanda 13, Bogor 16122, West Java, Indonesia. Tel: 62-813-1745-8626. E-mail: \\ reni001@lipi.go.id; reni_naa@yahoo.com
}

Received: August 25, 2020

doi:10.5539/jas.v12n11p78
Accepted: September 22, $2020 \quad$ Online Published: October 15, 2020

URL: https://doi.org/10.5539/jas.v12n11p78

The research is financed by the Competitive Program of the Indonesian Institute of Sciences in 2017 according to the Decision Letter of The Chairman of LIPI Number 1668/F/2016.

\begin{abstract}
There is a huge potential of upland for developing food crops to shortage the increase in rice production in Indonesia. Upland rice that adaptable to dry land could support national rice production. Among the limit factors of upland rice productivity in Indonesia are infertile land and cultivation practices. The purpose of the study was to find out the effect of microbial inoculant application combined with nitrogen $(\mathrm{N})$ fertilizer dosage to the cultivation of upland rice Inpago LIPI Go4. The factorial experimental design with two factors was applied, namely the supply of microbial inoculant and the dosage of $\mathrm{N}$ fertilizer and, i.e., $0 \%, 50 \%, 100 \% \mathrm{~N}\left(200 \mathrm{~kg} \mathrm{ha}^{-1}\right.$ Urea). The inoculant comprises of Aspergillus niger, Trichoderma viride, and Azotobacter. Each treatment combination was repeated four times. The microbial inoculant treatment solely effects significantly plant height, tiller number, and panicle weight of the upland rice, whereas $\mathrm{N}$ dosage treatment solely influences significantly plant height and tiller number. There was no interaction significant effect of microbial inoculant and $\mathrm{N}$ fertilizer dosage to all growth, production, and content of leaf $\mathrm{N}$ parameters. The maximum production of the upland rice was $4499 \mathrm{~kg} \mathrm{ha}^{-1}$, whereas the average production was $3816 \mathrm{~kg} \mathrm{ha}^{-1}$ grain weight. The highest yield was obtained from the plant with the supply of microbial inoculant and the treatment of $50 \% \mathrm{~N}$ fertilizer $\left(100 \mathrm{~kg} \mathrm{ha}^{-1}\right.$ Urea).
\end{abstract}

Keywords: upland rice, microbial inoculant, nitrogen fertilizer, growth, production

\section{Introduction}

The population growth of Indonesia is estimated at $24.4 \%$ from 258 million in 2015 to 321 million in 2050 (United Nations, 2015). In consequence of the population increasing of the country is the rising of food consumption requirements. Most Indonesian societies consume rice as the main staple food.

Rice consumption for 2017/2018 is maintained at 38.0 million tons in Indonesia, whereas the production of milled-rice was 37 million tons (Global Agricultural Information Network [GAIN], 2018). To cover up the shortcomings, Indonesia must import rice. In 2017/2018, rice import of Indonesian reached 2.15 million tons based on realized imports of state-owned purchasing and logistics agency BULOG (GAIN, 2018). Therefore, the country needs to increase the national rice production from new or more resources. Rice production in Indonesia generally resulted from lowland and irrigated areas, mostly in Java island. In the future, Indonesian agriculture cannot rely only on the irrigated lowland rice to support food production.

One way to shortage the increase in rice production in Indonesia is to utilize dry or upland for upland rice cultivation. The potential of upland in Indonesia for developing food crops is about 12.9-25.1 million ha and upland suitable for growing upland rice expansion is 5.1 million ha (Toha, 2012; Syuaib, 2016; Idjudin \& 
Marwanto, 2008). Therefore, upland rice that adaptable to dry land could also support the national rice production (Tarigan et al., 2019; Budiono \& Adinurani, 2017; Taridala et al., 2018). Only about 1 million ha has been used for upland rice cultivation (Suwarno, 2010), whereas according to the data, the total area of upland rice cultivation in Indonesia is 1.2 million ha with the productivity of $2560 \mathrm{~kg} \mathrm{ha}^{-1}$ or only about $50 \%$ of irrigated lowland rice productivity (Central Agency of Statistic [BPS], 2010). On the other hand, the potential production of new release upland rice variety in Indonesia and also upland rice production in Peru could reach 7100-7200 $\mathrm{kg} \mathrm{ha}^{-1}$ (De Datta, 1975; Jamil et al., 2016). The result of intensive cropping pattern research indicated that dry or upland could also produce up to $10000 \mathrm{~kg} \mathrm{ha}^{-1}$ year $^{-1}$ of grain equivalent, meaning that upland rice production is not inferior to irrigated lowland rice (Toha \& Fagi, 1995).

Among the limit factors of upland rice productivity, are infertile land and cultivation practices (Saito et al., 2006; Putra, 2011; Chaudhuri, 2015; Edi et al., 2015). The increase of upland rice productivity could be achieved through inorganic fertilization and bio-organic fertilization, such as in the form of microbial inoculant. The addition of $90 \mathrm{~kg} \mathrm{ha}^{-1}$ nitrogen $(\mathrm{N})$ fertilizer of new variety of upland rice cultivated in North Laos could increase its production from $3100 \mathrm{~kg} \mathrm{ha}^{-1}$ into $4000 \mathrm{~kg} \mathrm{ha}^{-1}$, whereas the local variety of upland rice production could increase from $1600 \mathrm{~kg} \mathrm{ha}^{-1}$ into $1900 \mathrm{~kg} \mathrm{ha}^{-1}$ (Saito et al., 2006).

The availability of soil nutrient of $\mathrm{N}$ and phosphor (P) sometimes become a problem for plants, due to $\mathrm{N}$ leaching and $\mathrm{P}$ bounding at the soil. The use of microbes, especially those that fixated $\mathrm{N}$ and dissolved $\mathrm{P}$ could support the availability and absorption of N and P for plants (Islam et al., 2016; Sarkar et al., 2012). The use of microbial inoculants at rice cultivation could reduce the requirements of inorganic fertilizers (Khan et al., 2017; Mulyaningsih et al., 2015).

In this study, we used upland rice Inpago LIPI Go4, as an upland rice cultivar has been released in 2014 by Research Center for Biotechnology, Indonesian Institute of Sciences. This upland rice was the result of the upland rice breeding research of Way Rarem variety and Vandana variety. According to the description of the variety (Jamil et al., 2016), the superiority of this upland rice variety is drought tolerance and reasonably tolerant to blast disease race 073 . The age of this upland rice plant is \pm 113 days, suitable to be planted in drought and low land with an altitude less than $700 \mathrm{~m}$ above sea level. The high productivity potency is $7100 \mathrm{~kg} \mathrm{ha}^{-1}$ with the average productivity is $4180 \mathrm{~kg} \mathrm{ha}^{-1}$.

The study aimed was to find out the effect of $\mathrm{N}$ fertilizer dosages combinate with microbes/organic application to the cultivation of upland rice Inpago LIPI Go4 to produce optimal and efficient yield. The results of the study will be very useful as practical guidelines and scientific information for the farmers, entrepreneurs, industrialists and also researchers in producing and studying the upland rice, especially cv Inpago LIPI Go4 to get optimal yield.

\section{Material and Methods}

\subsection{Location and Experimental Design}

The study was conducted at Cibinong Science Center and Botanic Gardens field, Bogor Regency, West Java Province in Indonesia from March until July 2017. The location of upland rice cultivation was $250 \mathrm{~m}$ above sea level, with minimum and the maximum average temperature in between $24.3{ }^{\circ} \mathrm{C}$ and $27.8{ }^{\circ} \mathrm{C}$, the average daily air humidity in between $66 \%$ and $93 \%$, average daily wind speed in between $3.6 \mathrm{~km} \mathrm{~h}^{-1}$ and $14.4 \mathrm{~km} \mathrm{~h}^{-1}$. The rainfall during the study was between $23.4 \mathrm{~mm}$ and $350 \mathrm{~mm}$ (Meteorology, Climatology, and Geophysical Agency [BMKG], 2018). Chemical soil analysis was conducted from four different block locations of the field before the study and from 24 plot study areas after study, including soil $\mathrm{pH}$, carbon $(\mathrm{C}), \mathrm{C} / \mathrm{N}$ ratio, available $\mathrm{N}$, and available $\mathrm{P}_{2} \mathrm{O}_{5}$ (Appendix A).

Suboptimal and Imperata cylindrica grassland area with alfisol soil type was planted with upland rice Inpago LIPI Go4. Before being planted, the soil was plowed and then mixed with compost as much as $15 \mathrm{~kg}$ per plot or $12500 \mathrm{~kg} \mathrm{ha}^{-1}$. The chemical content of the compost could be seen in Appendix B. Two Factorial Block Design was applied for the study, namely microbial inoculant application and $\mathrm{N}$ fertilizer (Urea) dosages. Microbial inoculants comprised of Aspergillus niger, Trichoderma viride, and Azotobacter. Microbial inoculant treatment comprised of control or without microbial inoculant application (C) and microbial inoculant application (I) was done one week after planted. On the other hand, three dosage treatments of $\mathrm{N}$ fertilizer applied were $0,50 \%$, $100 \%$ of the recommended dosage namely $200 \mathrm{~kg} \mathrm{ha}^{-1}$ of Urea ( $46 \%$ of $\left.\mathrm{N}\right)$. $\mathrm{N}$ fertilizer (Urea) was applied twice, namely in the same time of seeds planting and 4 weeks after planted. The study area was arranged with $4 \times 3 \mathrm{~m}^{2}$ plots for each combination treatment and was repeated 4 times at different blocks (24 in total). 


\subsection{Plant Cultivation and the Variables to be Analyzed}

Three seeds of upland rice Inpago LIPI Go4 were planted per hole with spacing $40 \times 15 \mathrm{~cm}^{2}$. Triple Super Phosphate $\left(44 \%-46 \% \mathrm{P}_{2} \mathrm{O}_{5}\right)\left(75 \mathrm{~kg} \mathrm{ha}^{-1}\right)$ and Potassium chloride $\left(60 \%-63 \% \mathrm{~K}_{2} \mathrm{O}\right)\left(50 \mathrm{~kg} \mathrm{ha}^{-1}\right)$ fertilizers were also applied at the time of seed planting. Plant growth parameters namely plant height, leaf number, and tillers number were analyzed at 3,5, and 7 weeks after planting (WAP). The flowering period occurred 7 WAP of an upland rice plant. The productivity of upland rice measured at harvest time (14 to $15 \mathrm{WAP}$ ) was dry biomass weight, seed weight, and panicle weight. $\mathrm{N}$ leaf content was also analyzed using Kjeldahl method. $0.5 \mathrm{~g}$ dry plant powder was digested with a Kjeldahl digestion unit (UDK 48, VELP Scientifica, U.S.) in boiling $98 \% \mathrm{H}_{2} \mathrm{SO}_{4}(10$ $\mathrm{ml}$ ) and catalyst (mix of $9.0 \mathrm{~g} \mathrm{~K}_{2} \mathrm{SO}_{4}$ and $1.0 \mathrm{~g} \mathrm{CuSO}_{4} \cdot 5 \mathrm{H}_{2} \mathrm{O}$ ). The samples were thereafter distilled in an Automatic Kjeldahl Distillation Unit (UDK 149, VELP Scientifica, U.S.) into $10 \mathrm{ml}\left(40 \% \mathrm{H}_{3} \mathrm{BO}_{3}\right)$, and subsequently were titrated with $0.02 \mathrm{~N} \mathrm{H}_{2} \mathrm{SO}_{4}$. $\mathrm{N}$ content was calculated and expressed as $\%$ of dry matter.

\subsection{Statistical Analysis}

All subject growth, productivity, and $\mathrm{N}$ content of plant leaf analysis were subjected to compare means continued with posthoc Duncan using Statistical Program SPSS 15.0 (SPSS Inc. Chicago, USA, 2006). The analysis comprises of solely the effect of microbial inoculant and the effect of $\mathrm{N}$ fertilizer dosage, as well as a combination between microbial inoculant and $\mathrm{N}$ fertilizer dosage.

\section{Results}

The summary of variance analysis for plant height parameter of upland rice at 3,5, and 7 WAP is presented in Table 1. Microbial inoculant treatment solely and nitrogen dosage treatment solely influenced significantly to plant height during 3, 5, and 7 WAP (Table 1). On the other hand, the interaction between microbial inoculant and nitrogen dosage treatments had no significant effects on plant height parameters during those 3 times of observation (Table 1). The microbial inoculant treatment solely increased plant height significantly namely $15 \%$ from $30.3 \mathrm{~cm}$ at $3^{\text {rd }}$ week, $8.4 \%$ from $49.7 \mathrm{~cm}$ at $5^{\text {th }}$ week, and $5.8 \%$ from $68.3 \mathrm{~cm}$ in the $7^{\text {th }}$ week, respectively (Figure 1A). At 7 WAP, microbial inoculant application treatment reached $72.3 \mathrm{~cm}$ height (Figure 1A). On the other hand, the treatment of $50 \%$ and $100 \%$ nitrogen fertilizer dosage resulted in a significantly higher upland rice plant as compared to $0 \% \mathrm{~N}$ fertilizer treatment at 3 and $5 \mathrm{WAP}$ (Figure 1B). The highest upland rice plants at 7 WAP was resulted from $100 \% \mathrm{~N}$ fertilizer treatment $(76.9 \mathrm{~cm})$, whereas the lowest plant $(64 \mathrm{~cm})$ resulted from $0 \% \mathrm{~N}$ fertilizer treatment (Figure 1B).

Table 1. Analysis of variance summary for the effect of microbial inoculant (M) and N fertilizer dosage (N) on plant height of upland rice Inpago LIPI Go4 at different age in Bogor regency, West Java, Indonesia

\begin{tabular}{llll}
\hline \multirow{2}{*}{ Sources } & \multicolumn{3}{c}{ Plant Height } \\
\cline { 2 - 4 } & 3 WAP & 5 WAP & 7 WAP \\
\hline $\mathrm{M}$ & $114.9^{* *}$ & $31.9^{* *}$ & $10.6^{* *}$ \\
$\mathrm{~N}$ & $3.7^{* *}$ & $11.2^{* *}$ & $19.7^{* *}$ \\
$\mathrm{M}^{*} \mathrm{~N}$ & 0.3 & 0.1 & 0.1 \\
\hline
\end{tabular}

Note. Value $=$ F Test; ${ }^{* *}$ statistically significant at 0.05 level probability (Using LSD Test). 


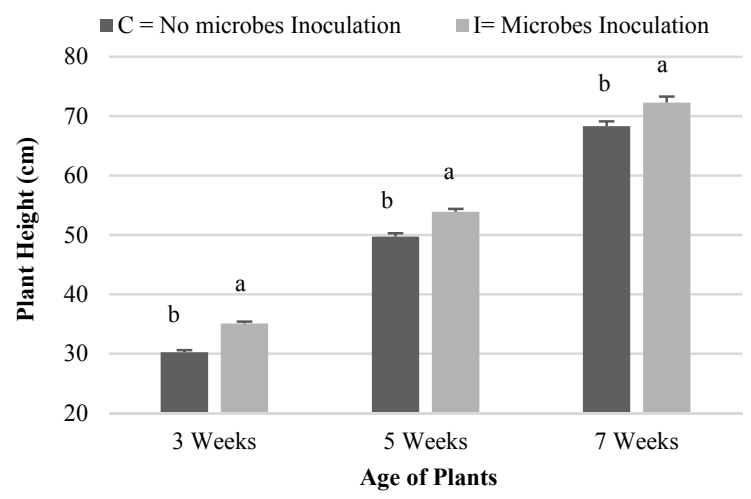

A

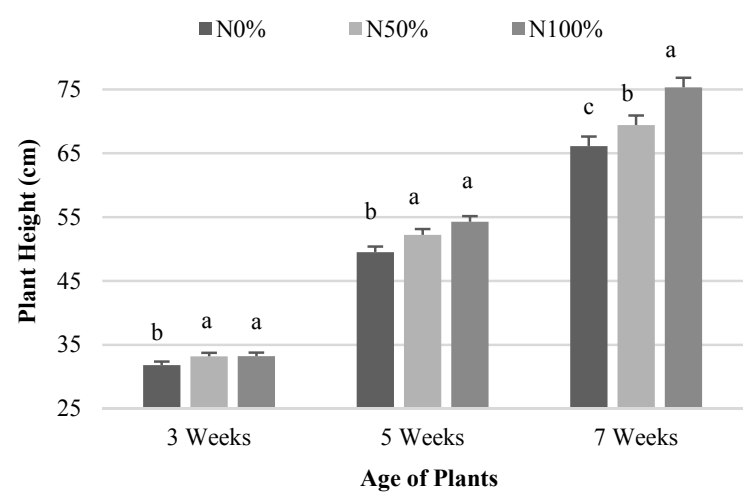

B

Figure 1. Plant height of upland rice Inpago LIPI Go4: (A) the microbial inoculant treatment solely at 3, 5, and 7 WAP, (B) the $\mathrm{N}$ fertilizer dosage treatment solely at 3,5, and 7 WAP. Different lowercase letters indicate a significant difference $(\mathrm{P} \leq 0.05)$

The summary of variance analysis for the effect of microbial inoculant application and $\mathrm{N}$ fertilizer dosage treatments on leaf number of upland rice Inpago LIPI Go4 at 3, 5, and 7 WAP is presented in Table 2. Whereas the detailed variance analysis is presented in Appendix 6 until 8. No significant influence of microbial inoculant application solely, nitrogen dosage fertilizer solely, and interaction between the treatments to the leaf number parameter at 3,5, and 7 weeks after planted (Table 2). Data on the leaf number at 7 WAP is presented in Table 5. The average leaf number of all treatments at 7 WAP was in between 4.30 and 4.53 (Table 5).

Table 2. Analysis of variance summary for the effect of microbial inoculant $(\mathrm{M})$ and $\mathrm{N}$ fertilizer dosage $(\mathrm{N})$ treatments on leaf number of upland rice Inpago LIPI Go4 at different age in Bogor regency, West Java, Indonesia

\begin{tabular}{llll}
\hline \multirow{2}{*}{ Sources } & \multicolumn{3}{c}{ Leaf Number } \\
\cline { 2 - 4 } & 3 WAP & 5 WAP & 7 WAP \\
\hline $\mathrm{M}$ & 0.9 & 0.4 & 0.2 \\
$\mathrm{~N}$ & 0.2 & 5.3 & 3.5 \\
$\mathrm{M}^{*} \mathrm{~N}$ & 0.1 & 1.0 & 0.6 \\
\hline
\end{tabular}

Note. Value $=\mathrm{F}$ Test.

Table 3 presented the summary of variance analysis for the effect of microbial inoculant and $\mathrm{N}$ fertilizer dosage on tiller number of upland rice Inpago LIPI Go4 at 3, 5, and 7 weeks after planted. There were significantly influenced by microbial inoculant treatment solely on the tiller number at 3 and 5 WAP. However, no significant effect of microbial inoculant treatment solely at $7 \mathrm{WAP}$, with the average tiller number was 21.0 (Table 3 and Figure 2A). Inoculant treatment could increase $40 \%$ of the tiller number from 4.5 into 6.4 at 3 WAP and increased $30 \%$ from 11.0 at 5 WAP respectively (Figure $2 \mathrm{~A}$ ). In contrast, the treatment of nitrogen dosage solely affected significantly to the tiller number at 5 and 7 WAP but no significant effect at an earlier stage of 3 WAP respectively (Table 4). The tiller number with $50 \%$ and $100 \%$ dosage treatments increased $19.3 \%$ and $29.0 \%$ respectively as compared to $0 \% \mathrm{~N}$ treatment (Figure 2B). While the treatment of $100 \%$ nitrogen fertilizer dosage resulted on the highest upland rice plants at 7 WAP $(76.9 \mathrm{~cm})$ and the highest number of tillage $(23.5 \mathrm{~cm})$, whereas the lowest plant $(64 \mathrm{~cm})$ and the lowest number of the tiller $(18.3 \mathrm{~cm})$ were those of the treatment $0 \% \mathrm{~N}$ (Figure 2A). On the other hand, there was no significant interaction effect between microbial inoculant and nitrogen fertilizer dosage treatments to tiller number parameter during 3 times observation (Table 3 ). 
Table 3. Analysis of variance summary for the effect of microbial inoculant $(\mathrm{M})$ and $\mathrm{N}$ fertilizer dosage $(\mathrm{N})$ on tiller number of upland rice Inpago LIPI Go4 at different age in Bogor regency, West Java, Indonesia

\begin{tabular}{llll}
\hline \multirow{2}{*}{ Sources } & \multicolumn{3}{c}{ Tiller Number } \\
\cline { 2 - 4 } & $3 \mathrm{WAP}$ & $5 \mathrm{WAP}$ & 7 WAP \\
\hline $\mathrm{M}$ & $0.8^{* *}$ & $9.8^{* *}$ & 10.7 \\
$\mathrm{~N}$ & 42.0 & $37.0^{* *}$ & $0.04^{* *}$ \\
$\mathrm{M} * \mathrm{~N}$ & 0.4 & 1.3 & 0.9 \\
\hline
\end{tabular}

Note. Value $=$ F Test; $* *$ statistically significant at 0.05 level probability (Using LSD Test)
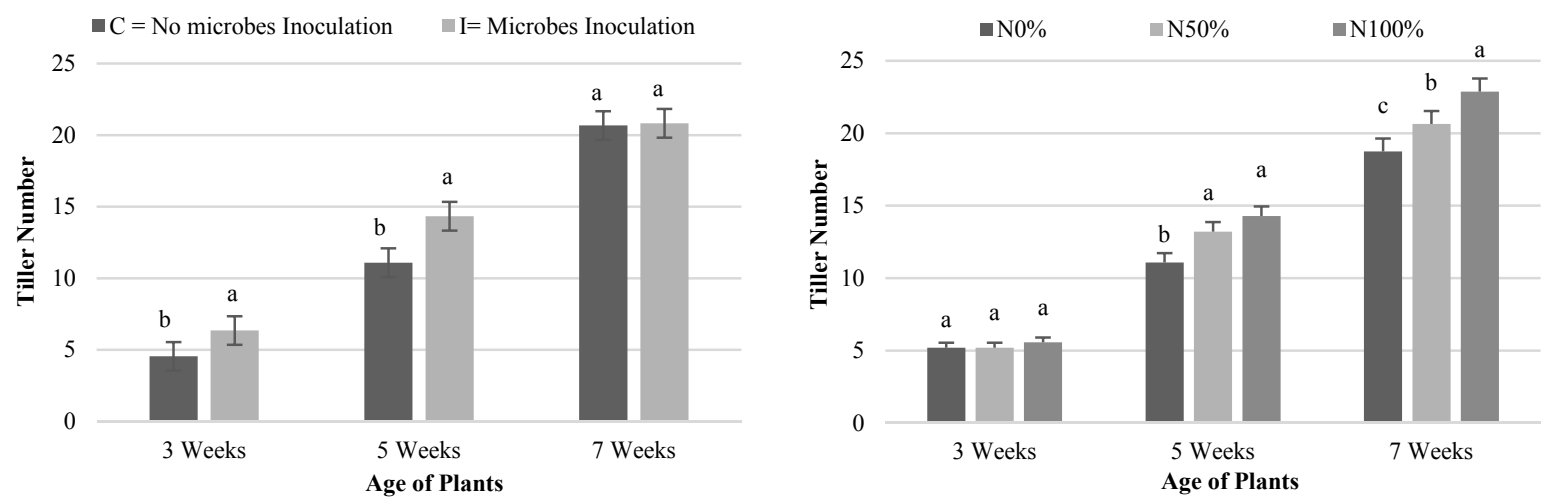

A B

Figure 2. Tiller number of upland rice Inpago LIPI Go4: (A) the microbial inoculant treatment solely at 3, 4, and 7 WAP, (B) the $\mathrm{N}$ fertilizer dosage treatment solely at 3, 5, and 7 WAP. Different lowercase letters indicate a significant difference $(\mathrm{P} \leq 0.05)$

The summary of the variance analysis of plant dry weight, panicle weight, and seed weight (production parameter), as well as $\mathrm{N}$ content of upland rice plant leaf, could be seen in Table 4. Microbial inoculant application treatment solely only influenced significantly to panicle weight, i.e., $34.910^{-3} \mathrm{~kg} \mathrm{plant}^{-1}$ (Figure 3). On the other hand, the results of the study showed that there was no significant influence of microbial inoculant treatment solely and nitrogen fertilizer dosage treatment solely as well as the interaction of both treatments to plant biomass dry weight, seed weight and $\mathrm{N}$ content of plant (Table 4). Plant dry weight of all treatments applied were in between $62.4010^{-3} \mathrm{~kg}$ and $83.1310^{-3} \mathrm{~kg}$, whereas seed weight was in between $15.9710^{-3} \mathrm{~kg}$ clump $^{-1}$ or $2661 \mathrm{~kg} \mathrm{ha}^{-1}$ and $27.010^{-3} \mathrm{~kg} \mathrm{clump}^{-1}$ or $4499 \mathrm{~kg} \mathrm{ha}^{-1}$ (Table 5), and the average was $22.1910^{-3} \mathrm{~kg}$ clump $^{-1}$ or $3816 \mathrm{~kg} \mathrm{ha}^{-1}$. On the other hand, the $\mathrm{N}$ content of upland rice plants of Inpago LIPI Go4 was between $0.69 \%$ and $0.85 \%$ (Table 5 ).

Table 4. Analysis of variance summary for the effect of microbial inoculant application (M) and $\mathrm{N}$ fertilizer dosage $(\mathrm{N})$ on dry weight, production parameter, and $\mathrm{N}$ leaf content of upland rice Inpago LIPI Go4

\begin{tabular}{lllll}
\hline Sources & $\begin{array}{l}\text { Plant Dry Weight } \\
\left(10^{-3} \mathrm{~kg} \mathrm{clump}^{-1}\right)\end{array}$ & $\begin{array}{l}\text { Panicle Weight } \\
\left(10^{-3} \mathrm{~kg} \mathrm{plant}^{-1}\right)\end{array}$ & $\begin{array}{l}\text { Seed Weight } \\
\left(10^{-3} \mathrm{~kg} \mathrm{clump}^{-1}\right)\end{array}$ & $\begin{array}{l}\text { N Content of Plant } \\
(\%)\end{array}$ \\
\hline $\mathrm{M}$ & 0.07 & $0.58^{*}$ & 0.04 & 0.80 \\
$\mathrm{~N}$ & 1.02 & 3.87 & 1.28 & 2.49 \\
$\mathrm{M}^{*} \mathrm{~N}$ & 0.43 & 0.22 & 0.82 & 1.04 \\
\hline
\end{tabular}

Note. Value $=$ F Test; ${ }^{*}$ statistically significant at 0.1 level probability (Using LSD Test). 


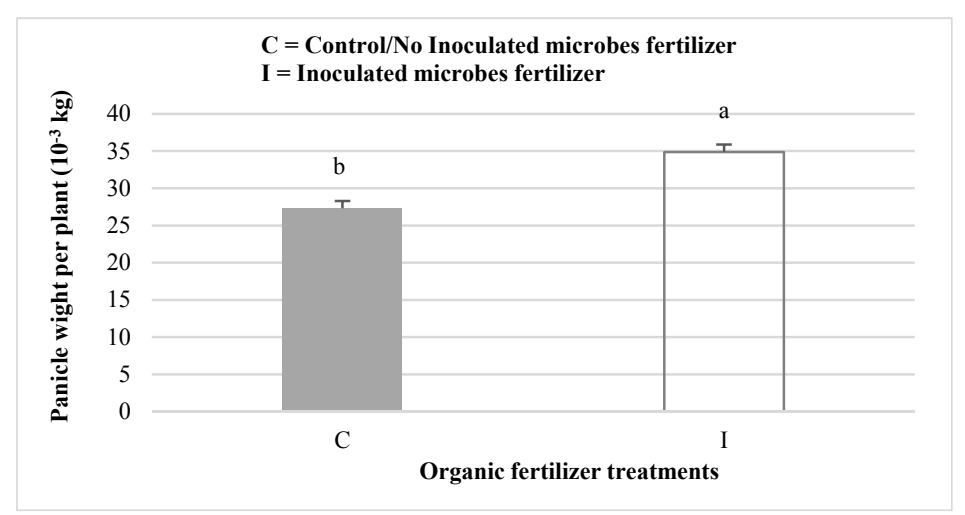

Figure 3. Panicle weight of upland rice Inpago LIPI Go4 of the microbial inoculant treatment solely. Different lowercase letters indicate a significant difference $(\mathrm{P} \leq 0.05)$

Table 5. All parameters that had no significant effects due to different microbial inoculant and $\mathrm{N}$ fertilizer dosage treatments

\begin{tabular}{lllll}
\hline Treatments & $\begin{array}{l}\text { Leaf Number } \\
\text { at 7 WAP }\end{array}$ & $\begin{array}{l}\text { Plant Dry Weight } \\
\left(10^{-3} \mathrm{~kg} \mathrm{clump}^{-1}\right)\end{array}$ & $\begin{array}{l}\text { Seed Weight } \\
\left(10^{-3} \mathrm{~kg} \mathrm{clump}^{-1}\right)\end{array}$ & $\begin{array}{l}\text { N Content of Plant } \\
(\%)\end{array}$ \\
\hline $\mathrm{CN} 0 \%$ & $4.44 \pm 0.30 \mathrm{~ns}$ & $62.40 \pm 15.8 \mathrm{~ns}$ & $21.45 \pm 7.08 \mathrm{~ns}$ & $0.83 \pm 0.13 \mathrm{~ns}$ \\
$\mathrm{CN} 50 \%$ & $4.53 \pm 0.29 \mathrm{~ns}$ & $63.34 \pm 14.1 \mathrm{~ns}$ & $15.97 \pm 7.76 \mathrm{~ns}$ & $0.85 \pm 0.19 \mathrm{~ns}$ \\
$\mathrm{CN} 100 \%$ & $4.40 \pm 0.24 \mathrm{~ns}$ & $73.59 \pm 22.8 \mathrm{~ns}$ & $22.63 \pm 8.08 \mathrm{~ns}$ & $0.83 \pm 0.07 \mathrm{~ns}$ \\
$\mathrm{IN} 0 \%$ & $4.30 \pm 0.22 \mathrm{~ns}$ & $75.19 \pm 16.0 \mathrm{~ns}$ & $24.03 \pm 7.14 \mathrm{~ns}$ & $0.71 \pm 0.05 \mathrm{~ns}$ \\
$\mathrm{IN} 50 \%$ & $4.33 \pm 0.28 \mathrm{~ns}$ & $83.13 \pm 34.6 \mathrm{~ns}$ & $27.00 \pm 11.34 \mathrm{~ns}$ & $0.69 \pm 0.08 \mathrm{~ns}$ \\
$\mathrm{IN} 100 \%$ & $4.38 \pm 0.25 \mathrm{~ns}$ & $71.21 \pm 34.1 \mathrm{~ns}$ & $22.04 \pm 13.15 \mathrm{~ns}$ & $0.85 \pm 0.19 \mathrm{~ns}$ \\
\hline
\end{tabular}

Note. Means \pm SD followed by ns or not significantly different at probability 0.05 level according to (LSD) test.

\section{Discussion}

The microbial inoculant application solely increased significantly to plant height and tiller number of upland rice Inpago LIPI Go4 (Tables 1 and 3, Figures 1A and 2A). Similar results on the effect of microbial inoculant Trichoderma viride and Bacillus megaterium to the growth of rice were reported by Al-Taweil et al. (2009). Improved of upland rice plant growth induced by microbes could be due to its association with rice through the production of IAA, solubilization phosphate, and other mechanisms (Khan et al., 2017). From the results, it could also be seen that microbial inoculant application treatment solely influenced on generative phase/production of the plant (panicle weight) (Table 4 and Figure 3). The fact that upland rice plants of the microbial inoculant application were higher and more weight of panicle than those without microbial inoculant application showed that the microbes inoculated could survive and possibly multiply/proliferate. Those mixture microbes as also explained by Bashan (1998) possibly could interact with each other synergistically, providing nutrients, removing inhibitory products, and stimulating each other through physical or biochemical activities that may enhance some beneficial aspects of their physiology, like nitrogen fixation. The microbes could also then provide/increase available $\mathrm{P}$ or other enzymes or plant growth-promoting effect at the soil that is needed during vegetative growth and generative period of plants (Khan et al., 2017; Jamily et al., 2019). The capability of microbes to compete with microbes that already available at the soil depended on the capability of the microbes to survive following by multiplying at the new environmental conditions of the soil (Gyaneshwar et al., 2002).

On the other hand, $\mathrm{N}$ fertilizer dosage treatment solely influenced mostly on the vegetative phase of plants (plant height and tiller number) (Tables 1 and 3, Figure 1B and 2B). Similar effects of $\mathrm{N}$ fertilizer dosage were also explained by some other studies to rice plants (Sekhar et al., 2014; Sikuku et al., 2015; Chaudhuri, 2015). The addition of $\mathrm{N}$ as macronutrient enhanced plant growth and development since $\mathrm{N}$ has roles as a component of chlorophyll, enzyme, protein, and nucleic acid which support the growth mechanism of the plant (Marschner, 1995), i.e., N nutrition influences the content of photosynthetic pigments, the synthesis of the enzymes taking part in the carbon reduction and the formation of the membrane system of chloroplast (Chaturvedi, 2005). The impact of significant growth of upland rice due to the application of $\mathrm{N}$ fertilizers in this study could be the 
attribute of important constituents of nucleotides, proteins, chlorophyll, and enzymes, involve in various metabolic processes that have a direct impact on the vegetative of plants.

No significant effect of $\mathrm{N}$ dosage treatment on the production and $\mathrm{N}$ plant content of upland rice in this study. The availability of $\mathrm{N}$ is needed also during the reproductive phase for the formation and the filling of rice seed (Chaudhuri, 2015), therefore $\mathrm{N}$ fertilizer should also be provided at the beginning of the reproductive phase (Jemberu et al., 2015; Hirzel \& Rodriguez, 2013). N fertilizer of upland rice cultivation at this study was provided at the vegetative phase, i.e. at the beginning of seed sowing and at one month after seed sowing. Available $\mathrm{N}$ resource may be utilized only for vegetative growth and the resource could not enhance upland rice production significantly in this study. On the other hand, the N content of upland rice plants of Inpago LIPI Go4 was in between $0.69 \%$ and $0.85 \%$ (Table 5). Similar findings of $\mathrm{N}$ concentration in rice plants due to the effect of increasing N fertilizer application rates have been reported by Hirzel and Rodriguez (2013), which were fluctuated between $0.51 \%$ and $0.77 \%$. N content of plants is influenced not only by the addition of $\mathrm{N}$ nutrient to the soil and cultivar of rice plants but also the type of soil and the environments, including climate and season (Hirzel \& Rodriguez, 2013).

The maximum production of seed weight from the study was $4499 \mathrm{~kg} \mathrm{ha}^{-1}$ (Table 5). Another study on the additional application of microbial inoculant Azospirillum and Asotobacter other than inorganic fertilizer to upland rice Inpago LIPI Go2 produced a similar result, with maximum productivity $4500-5200 \mathrm{~kg} \mathrm{ha}^{-1}$ (Mulyaningsih et al., 2015).

\section{Conclusion}

$\mathrm{N}$ dosage treatment solely significantly influences plant height and tiller number, whereas microbial inoculant treatment solely significantly affects plant height, tiller number, and panicle weight of the upland rice Inpago LIPI Go4. The maximum production of the upland rice was $4499 \mathrm{~kg} \mathrm{ha}^{-1}$, whereas the average production was $3816 \mathrm{~kg} \mathrm{ha}^{-1}$ grain weight. The highest yield was obtained from the plant with the supply of microbial inoculant and the treatment of $50 \% \mathrm{~N}$ fertilizer $\left(100 \mathrm{~kg} \mathrm{ha}^{-1}\right.$ Urea). Further study is needed to elucidate the detailed mechanism of microbial inoculant applications that affect plant growth and production. Other required studies on the upland rice are concerning the application of $\mathrm{N}$ fertilizer source other than Urea as well as different application timing.

\section{Acknowledgements}

The research regarded cultivation the upland rice Inpago LIPI Go4 at Bogor regency, West Java, Indonesia was supported by Competitive Program of the Indonesian Institute of Sciences in 2017 according to Decision Letter of the Chairman of LIPI Number 1668/F/2016. The authors thank all colleagues that support the study especially the fieldwork.

\section{References}

Al-Taweil H. I., Bin Osman, M., Hamid, A. A., \& Yusoff, W. M. W. (2009). Development of microbial inoculants and the impact of soil application on rice seedlings growth. American Journal of Agricultural and Biological Sciences, 4(1), 79-82. https://doi.org/10.3844/AJAB.2009.79.82

Bashan, Y. (1998). Inoculants of plant growth-promoting bacteria for use in agriculture. Biotechnology Advances, 16(4), 729-770. https://doi.org/10.1016/S0734-9750(98)00003-2

Budiono, R., \& Adinurani, P. G. (2017). Efficiency analysis of producing factors utilization in upland rice farming. In R. H. Setyobudi, M. G. M. Purwanto, J. Burlakovs, M. Mel, P. G. Adinurani, \& Z. Zane Vincēviča-Gaile (Eds.), NRLS Conference Proceedings of the International Conference 2016 on Natural Resources and Life Sciences (pp. 180-187). Dubai: KnE Life Sciences. https://doi.org/10.18502/ kls.v3i5.991

Central Agency of Statistics. (2010). Statistical Yearbook of Indonesia. Jakarta: BPS (Central Agency of Statistic).

Chaturvedi, I. (2005). Effect of nitrogen fertilizers on growth, yield and quality of hybrid rice (Oriza sativa). Journal of Central Europian Agriculture, 6(4), 611-618. Retrieved from https://hrcak.scre.hr/17330

Chaudhuri, P. B. (2015). Nitrogen nutrition in rice. Indian Journal of Plant Sciences, 4(3), 28-37.

De Datta, S. K. (1975). Upland rice around the world. Major research in upland rice. Los Banos, Philippine: The International Rice Research Institute. 
Edi, S., Mildaerizanti, \& Nofriati, D. (2015). The study of growth and result potential of tolerant drought of local varieties upland rice. In S. Herlinda, Suwandi, Tanbiyaskur, D. Nusyamsi, M. Noor, S. Anwar, ... M. I. Syafutri (Eds.), Prosiding Seminar Nasional Lahan Suboptimal 2015. Palembang, Indonesia: Unsri Press.

Global Agricultural Information Network. (2018). Indonesia grain and feed update 2018. GAIN Report. USDA Foreign Agricultural Service, USA.

Gyaneshwar, P., Naresh Kumar, G., Parekh, L. J., \& Poole, P. S. (2002). Role of soil microorganisms in improving P nutrition of plants. Plant Soil, 245, 83-93. https://doi.org/10.1023/A:1020663916259

Hirzel, J., \& Rodriguez, F. (2013). Increasing nitrogen rates in rice and its effect on plant nutrient composition and nitrogen apparent recovery. Chilean Journal of Agricultural Research, 73(4), 385-390. https://doi.org/ 10.4067/S0718-58392013000400009

Idjudin, A. A., \& Marwanto, S. (2008). Reformation of dryland management for supporting food-self-sufficiency (in Indonesian). Jurnal Sumberdaya Lahan, 2(2), 115-125.

Islam, S., Akanda, A. M., Prova, A., Islam, M. T., \& Hossain, M. M. (2016). Isolation and identification of plant growth promoting rhizobacteria from cucumber rhizosphere and their effect on plant growth promotion and disease suppression. Frontiers in Microbiology, 6, 1360. https://doi.org/10.3389/ fmicb.2015.01360

Jamil, A., Mejaya, M. J., Praptana, R. H., Subekti, N. A., Aqil, M., Musaddad, A., \& Putri, F. (2016). Description of Superior variety of food crop 2010-2016. Indonesian Agency for Agricultural Research and Development. Jakarta: Ministry of Agriculture.

Jamily, A. S., Koyama, Y., Win, T. A., Toyota, K., Chikamatsu, S., Shirai, T., ... Yasuhara, T. (2019). Effects of inoculation with a commercial inoculant Bacillus subtillis C-3120 mixture on rice and barley growth and its possible mechanism in the plant growth stimulatory effect. Journal of Plant Protection Research, 59(2), 193-205. https://doi.org/10.24425/jppr.2019.129284

Jemberu, T., Togashi, M., \& Urayama, H. (2015). Nitrogen fertilizer application timing on growth and yield of NERICA 4 and Japanese rice variety Toyohatamochi. International Research Journal of Agricultural Science and Soil Science, 5(3), 91-97.

Khan, M. M. A., Haque, E., Paul, N. C., Khaleque, M. A., Al-Garni, S. M. S., Rahman, M., \& Islam, M. T. (2017). Enhancement of growth and grain yield of rice in nutrient deficient soils by rice probiotic bacteria. Rice Science, 24(5), 264-273. https://doi.org/10.1016/j.rsci.2017.02.002

Marschner, H. (1995). Mineral nutrition of higher plants (2nd ed.). San Diego: Academic Press.

Meteorology, Climatology, and Geophysical Agency. (2018). Climate Data: Data Online, Pusat Database $B M K G$. Retrieved on February 4, 2019, from http://dataonline.bmkg.go.id/home

Mulyaningsih, E. S., Sukiman, H., Ermayanti, T. M., Lekatompessy, S., Indrayani, S., Seri, A. R., \& Adi, E. B. M. (2015). Response of upland rice to organic fertilizer at dry land in Konawe Selatan district of South East Sulawesi. Jurnal Pengkajian dan Pengembangan Teknologi Pertanian, 18(3), 251-261.

Putra, S. (2011). Plant spacing effect on improving upland rice yield of situ patenggang variety. Jurnal Agrin, 15(1), 54-63.

Saito, K., Linquist, B., Atlin, G. N., Phanthaboon, K., Shiraiwa, T., \& Horie, T. (2006). Response of traditional and improved upland rice cultivars to $\mathrm{N}$ and $\mathrm{P}$ fertilizer in northern Laos. Field Crops Research, 96(2-3), 216-223. https://doi.org/10.1016/j.fcr.2005.07.003

Sarkar, A, Islam, T., Biswas, G. C., Alam, M. S., Hossain, M., \& Talukder, N. M. (2012). Screening for phosphate solubilizing bacteria inhabiting the rhizoplane of rice grown in acidic soil in Bangladesh. Acta Microbiologica Immunologica Hungarica, 59, 199-213.

Sekhar, D., Prasad, P. V. N., Rao, K. T., \& Rao, N. V. (2014). Productivity of rice as influenced by planting method and nitrogen source. International Journal of Current Microbiology and Applied Sciences, 3(8), 1063-1068. https://doi.org/10.1556/AMicr.59.2012.2.5

Sikuku, P. A., Kimani, J. M., Kamau, J. W., \& Njinju, S. (2015). Evaluation of different improved upland rice varieties for low soil nitrogen adaptability. International Journal of Plant \& Soil Science, 5(1), 40-49. https://doi.org/10.9734/IJPSS/2015/13637

Suwarno. (2010). The increasing rice production towards sustainable food security. PANGAN, 19(3), $233-243$. 
Syuaib, M. F. (2016). Sustainable agriculture in Indonesia: Facts and challenges to keep growing in harmony with the environment. Agricultural Engineering International, 18(2), 170-184.

Taridala, S. A. A., Abdullah, W. G., Suaib, Wahyuni, S., Wianti, N. I., Zani, M., ... Ekaputri, A. S. (2018). IOP Conf. Series: Earth and Environ. Sci. (Vol. 122, pp. 1-7). https://doi.org/10.1088/1755-1315/122/1/012066

Tarigan, P. J., Tohari, P., \& Suryanto. (2019). Physiological response of upland rice varieties to the furrow with organic matter on agroforestry system with kayu putih (Melaleuca leucadendra L.). Journal of Sustainable Agriculture, 34(2), 223-231. https://doi.org/10.20961/carakatani.v3412.29786

Toha, H. M. (2012). Development of upland rice to resolve food dangerous at marginal areas. In A. Dariah., B. Kartiwa, N. Sitrisno, K. Suradisastra, M. Sarwani, H. Soeparno, \& E. Pasandaran (Eds.), The prospect of dryland agriculture to support food security. Indonesian Agency for Agricultural Research and Development, Ministry of Agriculture, Jakarta.

Toha, H. M., \& Fagi, M. A. (1995). Food crop cultivation and conservation farming system in river flow area jratunseluna upstream part (3rd ed.). Indonesian Agency for Agricultural Research and Development, Ministry of Agriculture, Jakarta.

United Nation. (2015). World Population Prospect 2015. Economic \& Social Affairs, United Nations.

\section{Appendix A.}

\section{Chemical Content of The Soil at Upland Rice Cultivation Area}

\begin{tabular}{lllll}
\hline No. & Chemical Content & Amount & Category & Methods \\
\hline 1 & $\mathrm{pH} \mathrm{H} \mathrm{H}_{2} \mathrm{O}$ & $5.69-6.06$ & rather acid & Potensiometry/pH meter \\
2 & C-organic (\%) & $0.99-1.49$ & very low-low & Walkey \& Black \\
3 & N-total (\%) & $0.11-0.16$ & very low & Kjeldahl \\
4 & C/N Ratio & $8.68-9.80$ & Low & Calculation \\
5 & $\mathrm{P}_{2} \mathrm{O}_{5}$ available $(\mathrm{ppm})$ & $5.1-48.6$ & Low-very high & Olsen \\
6 & $\mathrm{~K}_{2} \mathrm{O}$ available $(\mathrm{ppm})$ & $16.54-72.01$ & Low-very high & $\mathrm{CH}_{3} \mathrm{COONH}_{4} 1 \mathrm{~N}$ \\
7 & Ion Change Capacity $(\mathrm{cmol}(+) / \mathrm{kg}$ & $10.01-10.84$ & Low & $\mathrm{CH}_{3} \mathrm{COONH}_{4} 1 \mathrm{~N}$ \\
8 & Texture & & Clay, Silty clay & Pipette \\
\hline
\end{tabular}

\section{Appendix B.}

\section{Chemical Content of Compost that Applied to The Field Plots of Upland Rice Plants}

\begin{tabular}{|c|c|c|c|}
\hline No. & Chemical Content & Amount & Methods \\
\hline 1 & $\mathrm{pH} \mathrm{H}_{2} \mathrm{O}$ & 6.6 & Potensiometry/pH meter \\
\hline 2 & Water content $(\%)$ & 59.00 & Gravimetry \\
\hline 3 & C-organic $(\%)$ & 12.77 & Oxidation/Gravimetry \\
\hline 4 & $\mathrm{~N}$-total $(\%)$ & 1.27 & CNS Analyzer \\
\hline 5 & C/N Ratio & 10 & Calculation \\
\hline 6 & $\mathrm{P}_{2} \mathrm{O}_{5}$ total $(\%)$ & 0.17 & $\mathrm{HNO}_{3} /$ Spectrophotometry \\
\hline 7 & $\mathrm{~K}_{2} \mathrm{O}$ total $(\%)$ & 0.16 & $\mathrm{HNO}_{3} / \mathrm{F}-\mathrm{AAS}$ \\
\hline 8 & $\mathrm{Na}$ total $(\%)$ & 0.01 & $\mathrm{HNO}_{3} / \mathrm{F}-\mathrm{AAS}$ \\
\hline 9 & Ca total $(\%)$ & 1.82 & $\mathrm{HNO}_{3} / \mathrm{F}-\mathrm{AAS}$ \\
\hline 10 & $\mathrm{Mg}$ total $(\%)$ & 0.29 & $\mathrm{HNO}_{3} / \mathrm{F}-\mathrm{AAS}$ \\
\hline 11 & Fe total (ppm) & 12006 & $\mathrm{HNO}_{3} / \mathrm{F}-\mathrm{AAS}$ \\
\hline 12 & Mn total (ppm) & 667 & $\mathrm{HNO}_{3} / \mathrm{F}-\mathrm{AAS}$ \\
\hline 13 & $\mathrm{Cu}$ total (ppm) & 15 & $\mathrm{HNO}_{3} / \mathrm{F}-\mathrm{AAS}$ \\
\hline 14 & $\mathrm{Zn}$ total (ppm) & 5 & $\mathrm{HNO}_{3} / \mathrm{F}-\mathrm{AAS}$ \\
\hline 15 & $\mathrm{~Pb}$ total $(\mathrm{ppm})$ & 11 & $\mathrm{HNO}_{3} / \mathrm{F}-\mathrm{AAS}$ \\
\hline 16 & Cd total (ppm) & 0.8 & $\mathrm{HNO}_{3} / \mathrm{F}-\mathrm{AAS}$ \\
\hline 17 & As total (ppm) & Not detected & $\mathrm{HNO}_{3} / \mathrm{F}-\mathrm{AAS}$ \\
\hline 18 & $\mathrm{Hg}$ total (ppm) & 0.1 & $\mathrm{HNO}_{3} / \mathrm{F}-\mathrm{AAS}$ \\
\hline 19 & Ion Change Capacity $(\mathrm{cmol}(+) / \mathrm{kg}$ & 16.84 & $\mathrm{NH}_{4} \mathrm{OAC} \mathrm{pH} 7 /$ Auto Analyzer \\
\hline 20 & Humic acid (\%) & 1.89 & Gravimetry \\
\hline
\end{tabular}




\section{Copyrights}

Copyright for this article is retained by the author(s), with first publication rights granted to the journal.

This is an open-access article distributed under the terms and conditions of the Creative Commons Attribution license (http://creativecommons.org/licenses/by/4.0/). 